\title{
TAQNĪN AL-AHKĀM \\ (Telaah Sejarah Legislasi Hukum Perdata Islam dalam Hukum Nasional Indonesia)
}

\author{
Miftahul Ulum \\ STAI Syaichona Moh. Cholil Bangkalan \\ Email: miftahul ulum2001@,yahoo.com \\ Moh. Mujibur Rohman \\ Program Studi Hukum Keluarga Islam, Pascasarjana IAIN Madura \\ Email: mujibur.rohman6568@gmail.com \\ Mohsi \\ STAI Miftahul Ulum Pamekasan \\ Email: silamohsi@gmail.com
}

\begin{abstract}
In establishing law (istinbath al-hukm) Islam uses an approach to the al-Qur'an and al-Hadith, where both are references to all legal problems. Indonesia is a country with the largest majority of Muslims in the world. Not so, the existence of Indonesia as a law state that adheres to a democratic system requires the existence of Islamic legal legislation from living law to legal law. Where, Fiqh began to be formulated into constitution. Therefore, Indonesia, which is known as the trias politica government system (Judicative, Executive and Legislative), must also provide space for Muslims in the National Legislation Program (Prolegnas) to form Islamic law in Indonesia. This legislative process in Islam is known as Taqnīn Al-Ahkām (legal legislation).
\end{abstract}

Keywords: Taqnin al-Abkäm, Islamic Civil Law Legislation.

Abstrak
Dalam penetapan hukum (istinbath al-bukm), Islam menggunakan pendekatan
terhadap al-Qur'an dan al-Hadis, dimana kedua merupakan rujukan segala
problematika hukum. Indonesia merupakan negara dengan mayoritas pemeluk
agama Islam terbesar di dunia. Tidak demikian, adanya Indonesia sebagai negara
hukum yang menganut sistem demokrasi menuntut adanya legislasi hukum
Islam dari living Law menjadi Legal Law. Dimana, Fiqh mulai dirumuskan
menjadi undang-undang dasar. Oleh karenanya Indenesia yang dikenal dengan
sitem pemerintahan trias politika (Yudikatif, Eksekutif dan Legislatif) harus
turut memberi ruang untuk umat Islam dalam Program Legislasi Nasional 
(Prolegnas) untuk membentuk hukum Islam di Indonesia. Proses legislasi ini dalam Islam dikenal dengan sebutan Taqnin Al-Abkäm (legislasi hukum).

Kata Kunci: Taqnin al-Abkeam, Legislasi Hukum Perdata Islam.

\section{Pendahuluan}

Islam adalah agama dengan penganut terbesar di Indonesia dari pada agama-agama lain yang di akui di Indonesia, seperti Kristen Protestan, Kattholit, Hindu dan Budha. Meski Islam adalah agama dengan penganut terbesar bukan berarti Indonesia adalah negara Islam. Indonesia adalah negara hukum (rechtstaat) yang beridiologikan pancasila, bukan sebuah negara kekuasaan (machstaats). Oleh sebab Indonesia sebagai negara hukum, maka semua peraturan yang berlaku di Indonesia adalah Undang-Undang. Yakni aturan mengikat bagi rakyatnya dengan keberagaman Ras, Suku, Budaya dan Agama.

Meskipun Indonesia bukan negara Islam, namun dalam perkembangan sejarah, hukum Islam diberlakukan di Indonesia (secara praktik, bukan tertulis) bersamaan dengan masuknya Islam ke Nusantara. Kendati demikian seiring perkembangan jaman serta adanya hukum yang dinamis, hukum Islam sudah mulai dilegalkan di Indonesia dengan dimasukkannya kedalam bentuk UndangUndang. Seperti, yang berkaitan dengan akuntabilitas publik atau tanggung jawab publik, yaitu undang-undang tentang zakat, wakaf, haji, peradilan agama, bank syariah dan Kompilasi Hukum Islam (KHI).

Memasukkan sebuah hukum Islam -hukum yang hidup (living law) di dalam masyarakat- menjadi sebuah peraturan atau undang-undang, dengan cara mengkodifikasi hukum itu sendiri, dalam Islam dikenal dengan taqnin al-abkeam (legislasi hukum). Taqni al-abkām itu sendiri adalah mengumpulkan beberapa hukum (kodifikasi hukum) dan kaidah penetapan hukum (tasyri') yang berkaitan dengan hubungan sosial yang kemudian disusun secara sistematis serta diungkapkan dengan kalimat-kalimat yang tegas, ringkas dan jelas dalam bentuk bab, pasal dan ayat yang memiliki nomor secara berurutan, yang kemudian ditetapkan sebagai undang-undang atau peraturan dan disahkan oleh pemerintah sehingga wajib ditegakkan oleh penegak hukum di tengah masyarakat". 1

Penelitian ini menggunakan pendekatan historical upproach dan statute upproach, dengan jenis penelitian kualitatif. Dengan menjadikan undang-undang

${ }^{1}$ Musthafa Ahmad al-Zarqā, al-Madkhal al-Fiqh al-'Āmī, Vol. 1 (Beirut: Dar al-Qalam, 2004), 313. 
sebagai sebagai rujukan dan sumber primer, mengingat yang menjadi obyek penelitian ini adalah tentang sejarah perundang-undangan hukum nasional, dimana sepanjang sejarah hukum nasional Indonesia, hukum Islam memberikan andil dalam pembentukan hukum. Dalam penelitian ini akan mengungkap sejarah bentuk-bentuk hukum Islam yang telah mendapatkan posisi dalam system hukum nasional, serta diskursus antar ulama` atas adanya pembentukan taqnin al-ahkam, bagaiaman juga pengaruh dan relevansinya dalam upaya membentuk hukum yang maslahah dan berkeadilan.

\section{Konseptualisasi Taqnīn al-Ahkām}

Berbicara mengenai taqnin al-abkäm tidaklah lengkap jika tidak mengetahui makna atau definisi dari taqnin al-abkām itu sendiri baik secara etimologi atau terminologi. Kata "تقنين" (taqnin) merupakan bentuk masdar yang dicetak dari fi’il madi “ "نّ " secara makna bahasa atau etimologi dalam bahasa Arab memiliki arti membuat, menetapkan, mengkodifikasikan (undangundang). ${ }^{2}$ Sama dengan taqnin yaitu kata qanūn “ قانون " yang mempunyai arti ukuran segala sesuatu, ada juga yang memberi makna jalan atau cara (thariqah), pemaknaan tersebut merupakan makna secara bahasa atau etimologi sedang secara istilah qanūn " قانون " itu sendiri adalah hal yang bersifat menyeluruh (amr al-kulliy) untuk mengetahui sebuah hukum, yang mencocoki terhadap bagiannya masing-masing. ${ }^{3}$

Kata " الأحكام" (al-abkeam) merupakan bentuk jamak atau plural dari kata " " (bukmun) yang artinya adalah hukum, peraturan, ketetapan dan keputusan. ${ }^{4}$ Secara terminologi “ "حكم" (bukmun) adalah khithab Allah (titah Allah) yang berhubungan dengan perbuatan orang mukallaf, baik berupa tuntutan atau pilihan atau berhubungan dengan sesuatu yang lebih umum secara wadl'i, yaitu khithab yang berlaku menjadi sebab, syarat, mani', shabih dan fasid. Jadi Taqnin alabkam “ تقنين الأحكام" adalah kata majmuk yang dalam gramatika Arab dikenal

\footnotetext{
${ }^{2}$ Atabik Ali \& A. Zuhdi Muhdlor, Kamus Kontemporer: Arab-Indonesia (Yogyakarata: Multi Karya Grafika, t.t.), 1474.

${ }^{3}$ Ibrahim Anis, al-Mu'jam al-Wasith, Vol. 2 (Beirut: Dar al-Ilmiyah, 1987), 763.

${ }^{4}$ Ahmad Warson Munawwir, Kamus al-Munawwir: Arab-Indonesia (Surabaya: Pustaka Progressif, 1997), 286.

${ }^{5}$ Zakariya al-Anshorī, Ghāyah al-Wushūl Syarh Lubbu al-Ushūl (Surabaya: al-Hidāyah, t.t.), 6.

${ }^{6}$ Kata majmuk adalah gabungan dari dua atau beberapa kata tetapi mempunyai satu makna.

87 | Ulümnâ: Jurnal Studi Keislaman
} 
dengan susunan idläfah (mudäf-mudäf ilaih) ${ }^{7}$. Kata taqnin al-abkēm sendiri memiliki arti kodifikasi beberapa hukum atau peraturan.

Pendapat lain mengatakan bahwa taqnin merupakan bahasa serapan dari bahasa Romawi yang berupa canon. Para orientalis barat seperti Goldziher, Van Kremer dan Scheldon Amos mengatkan bahwa syariat yang dibawa Muhammad Saw. seperti halnya hukum-hukum conanic (Romawi) yang diadopsi kedalam hukum-hukum Arab. Ia juga menegaskan argumennya dengan mengatakan bahwa Muhammad sebelum menjadi Rasul telah mengetahui hukum-hukum Romawi dengan melihat negri-negri yang menjadi kekuasaan imperium Romawi. Pernyataan tersebut terbantahkan melalui argumen para sarjana muslim yang mengatakan bahwa Nabi Muhammad Saw. lahir di mekah yaitu daerah yang bukan kekuasaan imperium Romawi. Selain itu Nabi tidak pernah keluar dari Makah sebelum diutus melainkan hanya dua kali. Pertama: pergi ke Syam bersama pamannya yaitu Abu Thalib. Kedua; ketika beliau berumur 25 tahun menjalankan bisnis Khadijah. Selain itu pendapat para sarjana muslim itu juga menegaskan bahwa syariat Islam dengan qanun Romawi mustahil bercampur karena syariat Islam berdasarkan Wahyu Allah Swt. Namun ada juga yang mengatakan bahwa kata taqnin berasal dari kata Persia. Meski demikian ada sebagian yang berpendapat sebaliknya, yaitu bangsa Romawi yang meng adopsi dari orang Arab (Islam). Pendapat ini dikemukan oleh Nallion, Fitzgerald, Abd. Razzaq dan Muhammad Yusuf Musa. ${ }^{8}$

Musthafa Ahmad al-Zarqā dalam kitabnya al-Madkhal al-Fiqh al-'Āmì menyatakan bahwa yang dimaksud taqnin secara umum adalah:

$$
\begin{aligned}
& \text { يقصد بالتقنين بوجه عام جمع الاحكام والقواعد التشرعية المتعلقة بمجال من مجالات العلاقات الاجتماعية, وتبويبها } \\
& \text { وترتيبها, وصياغتها بعبارات امرة موجزة واضحة في بنود تسمى (مواد) ذات ارقام متسلسلة. ثم إصدارها في صورة } \\
& \text { قانون أو نظام تفرضه الدولة, ويلتزم القضاة بتطبيقه بين الناس. }
\end{aligned}
$$

${ }^{7}$ Idlāfah atau susunan mudāf-mudāf ilaih secara etimologi adalah “ الإسناد ' menyandarkan. Sedangkan pengertian idläfah secara istilah atau terminologi adalah mengumpulkan isim dengan isim yang lain sehingga yang pertama tercegah dari harkah tanwin untuk menyempurnakan kedudukannya akibat adanya isim yang ke-dua. Isim yang pertama disebut $m u d \bar{a} f$ sedang isim yang kedua disebut mudāf ilaih. Lihat: Ibn Hamdūn, Hasyiyah Ibn Hamdūn, Vol. 1 (Surabaya: al-Hidayah, t.t.), 194.

${ }^{8}$ Abdul Karim Zaidan, al-Madkhāl li al-Darasah al-Syarì'ah al-Islāmiyah (Beirut: Resalah Publisher, 1969), 63. 
" Taqnin secara umum ialah Mengumpulkan beberapa hukum (kodifikasi hukum) dan kaidah penetapan hukum (tasyri) yang berkaitan dengan hubungan sosial yang kemudian disusun secara sistematis serta diungkapkan dengan kalimat-kalimat yang tegas, ringkas dan jelas dalam bentuk bab, pasal dan ayat yang memiliki nomor secara berurutan, yang kemudian ditetapkan sebagai undang-undang atau peraturan dan disahkan oleh pemerintah sehingga wajib ditegakkan oleh penegak hukum di tengah masyarakat".

Senada dengan pendapat Musthafa Ahmad al-Zarqā yaitu pendapat Muhammad Zakī Abdu al-Bar.

"Taqnin ialah Sebuah ibarat yang digunakan dalam mengumpulkan kaidahkaidah yang khusus dengan beberapa cabangnya (kodifikasi hukum) setelah disusun secara sistematis dengan cara menghilangkan pertentangan atau ketidak sinambungan dari kaidah hukum tersebut kemudian dibukukan menjadi satu dan dicetak serta di sahkan oleh pemerintah yang digunakan sebagai dasar (kewajiban) oleh penegak hukum. Adanya kaidah-kaidah hukum (tasyri'), kebiasaan ('urf), budaya ('Ádab), qadä' dan lainnya menjadi penyebab terbentuknya taqnin atau qanün."

Ia juga mengungkapkan dalam kitabnya Taqnin al-Fiqh al-Islami bahwa makna taqnin itu sendiri terdapat tiga makna. Pertma; penggunaan taqnin dalam bentuk umum yaitu taqnin yang bersumber dari (tasyri'), kebiasaan ('urf), budaya ('Ádab), qad $\bar{a}$ ' dan lainnya, seperti taqnin atau qanūn al-madani yaitu kaidah undang-undang khusus dalam transaksi keuangan yang bersifat pribadi. Kedua; kumpulan kaidah undang-undang khusus yang disusun secara sistematis tanpa adanya pertentangan antara satu peraturan dengan peraturan yang lain dengan menggunakan ibarat yang singkat. Ketiga; undang-undang (law) yang dibuat oleh pemerintah yang mempunyai kekuasaan hukum yang bersifat mengikat bagi setiap individu (baik pemerintah dan lainnya). ${ }^{11}$

\footnotetext{
${ }^{9}$ Musthafa Ahmad al-Zarqā, al-Madkhal al-Fiqh al- 'Āmī...., 313.

${ }^{10}$ Muhammad Zakī Abdu al-Bar, Taqnīn al-Fiqh al-Islāmī; al-Mabdā' wa al-Manhaj wa alTathbīq (Qatar: Idarah Ihya' al-Turats al-Islamī, 1986), 21.).

${ }^{11}$ Muhammad Zakī Abdu al-Bar, Taqnīn al-Fiqh al-Islāmī..., 21-22.

$89 \mid$ Ulümunâ: Jurnal Studi Keislaman
} 
Sobhi Mahmasani memaparkan sebagaimana dikutip oleh Imam Yazid, bahwa dalam konteks masa sekarang qanün atau taqnin mempunyai tiga arti. Pertama; pengertian yang sifatnya umum yaitu kumpulan aturan hukum (codex) seperti qanūn pidana Ustmani. Kedua; berarti syariat atau hukum. Ketga; dipakai secara khusus untuk kaidah-kaidah atau aturan yang tergolong dalam hukum muamalat umum yang mempunyai kekuatan hukum yakni undang-undang, seperti dewan legislatif membuat qanūn larangan menimbun barang. ${ }^{12}$

Qanūn atau taqnin dalam kajian ilmu hukum, seringkali diartikan sebagai kumpulan undang-undang atau hukum produk manusia yang dikemas untuk perkara tertentu dan bidang-bidang tertentu, seperti undang-undang pidana dan lain-lain. Bisa pula diartikan, sebagai kumpulan hukum produk manusia yang digunakan untuk menyelesaikan dan memutuskan manusia yang sedang berperkara. Qanūn produk manusi yang pertama kali dikenal adalah qanün bamuraby di negara Babilonia, sedang kumpulan qanün klasik yang paling terkenal adalah undang-undang Romawi. ${ }^{13}$

Setelah mengalami beberpa perkembangan, utamanya dalam masalah literatur hukum Islam. Muncullah istilah figh yakni ilmu yang mempelajari hukum syar'i yang berupa perbuatan ('amaliyah) yang diperoleh dengan penalaran beberapa dalil secara terperinci (tafsili). ${ }^{14}$ Selain istilah fiqh juga terdapat istilah fatwa yakni pendapat atau ketetapan ulama tentang suatu hukum, keputusan hakim (qadla) dan qanūn. ${ }^{15}$

Pada masa sekarang ini, qanūn dipandang sebagai formulasi hukum Islam, yakni aturan syara' yang dikodifikasi oleh pemerintah yang bersifat mengikat dan berlaku secara umum. Lahirnya qanūn (legislasi hukum Islam) dalam era moderen dalam suatu sisi dianggap sebagai kemajuan Islam dalam mengembangkan syariat-Nya serta menegakkan hukum-hukum yang ada di dalamnya. Atas dasar ini, sebagian ulama menganggap formulasi hukum Islam dianggap sebagai suatu yang penting sebagai panduan putusan hukum bagi para hakim dalam memutuskan masalah yang sama di peradilan yang berbeda-beda. Meski demikian, masih ada kalangan ulama yang menolak adanya taqnin al-abkeam (kodifikasi hukum) dengan argumentasi mereka sendiri.

\footnotetext{
${ }^{12}$ Imam Yazid, "Taqnin al-Ahkam; Sejarah, Keabsahan dan Tantangan di Indonesia" alMashlahah Journal Hukum dan Pranata Sosial Islam, No. 05, Vol. 3 (2015), 194.

${ }^{13}$ Rohidin, Pengantar Hukum Islam dari Semenanjung Arabia Sampai Indonesia (Yogyakarta: Lintang Rasi Aksara Books, 2016), 10.

${ }^{14}$ Zain al-Dīn bin Abdu al-'Azīz al-Malībārī, Fath al-Mu'̄̄n (t.tp: Gerbang Andalus, t.t.), 1.

${ }^{15}$ Jaih Mubarok, Hukum Islam (Bandung: Benang Merah Press, 2006), 1.
} 


\section{Sejarah Perkembangan Taqnīn al-Ahkām hingga Hukum Islam Indonesia}

Taqnin al-abkām atau yang sering dikenal dengan qanün dikaji dengan implikasi makna secara luas sesuai definisi yang bersifat umum (' $\bar{A} m$ ) dengan salah satu maknanya sebagai tasyri' (pembentukan hukum), maka keberadaan qanūn sudah bisa dipastikan di jaman Nabi Saw. Akan tetapi jika makna qanūn diartikan dalam konteks hukum sekarang, yaitu qanün yang bersifat mengikat, ditulis secara sitematis dengan menejemen yang baik (terkodifikasi baik) maka qanūn dalam konteks makna tersebut tidak akan ditemukan di jaman Nabi Saw.

Meski demikian dimasa Nabi Saw. pernah ada yang namanya shabifah madinah atau yang dikenal dengan sebutan piagam madinah yang berisi tentang hak dan kewajiban warga Madinah, baik muslim maupun non-muslim untuk menjaga kedaulatan Madinah. Oleh ahli hukum dikatakan bahwa piagam Madinah merupakan konstitusi negara yang tertulis. Sejak berdirinya pemerintahan Madinah ini, Nabi Muhammad Saw. sudah bertindak sebagai kepala negara. Beliau juga mengangkat pejabat-pejabat negara, termasuk sejumlah gubernur (wali) di berbagai wilayah, beliau juga menjalankan syariat Islam terhadap seluruh warga negara. Nabi Muhammad Saw. tidak menggunakan hukum adat, hukum persia ataupun hukum Romawi untuk memutuskan perkara (mengadili) di antra rakyatnya. ${ }^{16}$

Begitu juga di masa sahabat, ide tentang taqnin belum ditempuh. Ide yang baru muncul adalah pemushafan al-Qur'an yaitu mengumpulkan al-Qur'an dimasa khalifah Abu Bakar kedalam satu mushaf akibat terbunuhnya 70 pembesar sahabat penghafal al-Qur'an dalam peperangan yamämab (mi'rakatu alyamämah) atas usulan Umar ibn Khattab, pengumpulan al-Qur'an (jamu'ul qur'an) terus berlanjut dan berakhir di masa sahabat Ustman bin Affan. ${ }^{17}$ Bahkan hingga masa Bani Umayah taqnin belum juga ada, dimasa ini yang ada hanyalah pembukuan hadis (tadwin al-hadist) atas permintaan Umar bin Abdul Aziz (khilafah ke-delapan Bani Umayah dari kalangan tabi'in). ${ }^{18}$

Usulan adanya kodifikasi hukum (taqnin) baru muncul di masa Abbasiyah. Ide taqnin itu sendiri muncul dari seorang sekretaris negara yang

\footnotetext{
${ }^{16}$ Mujar Ibnu Syarif \& Khamami Zada, Fiqh Siyasah; Doktrin dan Pemikiran Politik Islam (t.tp: Erlangga, 2008), 81.

${ }^{17}$ Mannā' al-Qaththān, Tarikh al-Tasyri' al-Islāmī; al-Syarīah wa al-Fiqh (Riyad: Maktabah al-Ma'arif li al-Nasyri wa al-Tauzi', 1997), 191-192.

${ }^{18}$ Mannā' al-Qaththān, Tarikh al-Tasyri' al-Islāmī..., 287.

$91 \mid$ Ulumunà: Jurnal Studi Keislaman
} 
bernama Abdullah bin Muqaffa' yang mengusulkan idenya kepada khalifah Abi Ja'far al-Mansur (w. $158 \mathrm{H}$ ) untuk meninjau keberagaman hukum yang saling bertentangan. Ia mengatakan bahwa:

"Sebagian hal yang sangat penting diperhatikan oleh Amirul Mukminin adalah munculnya hasil keputusan para hakim yang saling bertentangan satu sama lain di berbagai wilayah dinasti Abbasiyah. Perbedaan hukum ini menjadi sangat penting diperhatikan karena dapat mebahayakan jiwa, harta dan kehormatan manusia (al-dimà' wa al-furüj wa al-amwäl). Amirul Mukminin juga harus mengambil sikap dengan meninjau serta menghimpun pendapat fuqab $\vec{a}$ yang terkuat dan relevan sebagai hukum materil yang nantinya akan dipakai disetiap peradilan. Hukum materil ini dijadikan pedoman yang bersifat mengikat bagi seluruh hakim disetiap peradilan. Demi terealisanya hal tersebut Khalifah harus menunjuk petugas khusus untuk setiap wilayah yang akan menghimpun hukum dengan menyesuaikan terhadap daerah tersebut serta menerapkan kaidahkaidah penerapannya". ${ }^{19}$

Ide kodifikasi hukum (taqnin) Ibn Muqaffa' ini tidak terealisasi, bahkan ide-nya dianggap sebuah penghianatan terhadap kepemimpinan Abi Ja'far al-Mansur dan di hukum oleh khalifah.

Terdapat suatu riwayat dari Ibn Katsir dalam Ikbtishär 'Ulüm al-Hadist bahwa Abi Ja'far al-Mansur menemui Imam Malik bin Anas (w. 179 H) dengan tujuan memerintahkan agar Imam Malik membuat suatu kitab yang dapat menyatukan manusia. Namun Imam Malik tidak berkenan akal hal itu karena manusia sudah mempunyai aliran atau pegangan tersendiri sesuai dengan wilayahnya masing-masing. Seperti penduduk Irak yang tidak akan sependapat dengan Imam Malik. Meskipun tidak sependapat dengan khalifah, namun akhirnya beliau mengarang kitab yang diberi nama al-Muwaththa.$^{20}$

\footnotetext{
${ }^{19}$ Bakr bin Abdullāh Abu Zaid, Fiqh al-Nawāzil; Qadlāyā Fiqhiyah Mu'āshirah, Vol. 1 (Beirut: Muassasah al-Dirāsah, 1996), 18-19.

${ }^{20}$ Terdapat banyak riwayat berkenaan hal ini, menurut al-Wāqidi yang mengarang kitab alMaghāzì bahwa yang bertemu dengan Imam Malik adalah al-Mahdi (w. $169 \mathrm{H})$ putra dari al-Mansur namun pendapat in termasuk pendapat yang harus ditinggalkan (matrūk). Sedang menurut riwayat lain adalah Harun al-Rasyid (w. $193 \mathrm{H}$ ) yang merupakan putra dari alMahdi sekaligus merupakan cucu dari al-Mansur. Ibn 'Asākir dan Ibn Abd. Bār bahwa keduanya yakni al-Mahdi dan Abi Ja'far al-Mansur sama-sama bertemu dengan Imam Malik. berdasarkan beberapa pendapat ayang ada Ibn Qayyim al-Jauziyah meberikan isyarah Vol.6 No. 1 Juni $2020 \mid 92$
} 
Joseph Schacht, dalam bukunya Pengantar Hukum Islam seperti dikutip oleh Imam Yazid, bahwa Perkembangan taqnin selanjutnya mulai lebih tampak pada masa Utsmani, yakni tepatnya masa kepemimpinan Sultan Sulaiman (1520$1560 \mathrm{M}$ ). Ia sangat serius dalam memberlakukan qanūn atau qanūn name sebagai hukum resmi. Atas usahanya itu Sultan Sulaiman di beri gelar Sulaiman alQanuni. Qanūn name mengupas secara lengkap gaji tentara, polisi rakyat yang bukan muslim, urusan kepolisian dan hukum pidana, hukum pertanahan dan hukum perang. Pada masa ini juga dikenal hukum kontrak yang kemudian disebut dengan majalah al-Adliyah. ${ }^{21}$

Berdasarkan perkembangannya pada masa kekuasaan dinasti Moghul (India) juga dihimpun suatu aturan hukum yang disebut fatawa alamghirriyah. Alamghirriyah merupakan suatu nama yang dinisbatkan kepada sultan Aurangzeb (1658-1707 M) dari dinasti Moghul. Namun ketika Inggris mengusai India (tahun $1772 \mathrm{M}$ ), terjadilah fusi antara hukum Islam yang sudah terealisasi di India dengan sistem hukum Inggris sehingga melahirkan istilah Anglo Mubammadan Law (Hukum Inggris Islam). Dalam merealisasikan peraturan ini, praktiknya para hakim-hakim Inggris dalam memutuskan hukum Islam didampingi oleh mufti-mufti agar bisa memutuskan hukum Islam dengan benar. ${ }^{22}$

Di Indonesia sendiri peradilan agama sudah ada sejak jaman kerajaankerajaan yang terdapat di beberapa daerah tertentu. Agama Islam tidak hanya menjadi agama resmi atau agama negara bahkan hukum yang diberlakukan adalah hukum Islam, seperti kerajaan Islam Pasai, Pagar Ruyung, Padri, kerajaan Islam Mataram di Jawa Tengah, kerajaan Islam Banjarmasin. Makasar dan Sebagainya. ${ }^{23}$

Pada Abad ke-VII Islam telah masuk keIndonesia dan telah di anut oleh sebagian besar orang Indonesia. ${ }^{24}$ Penerapan hukum Islam bukan hanya pada

\footnotetext{
bahwa Harun al-Rasyid yang bertemu dengan Imam Malik, hal ini seperti yang telah di sebutkan di dalam kitabnya 'I'lām al-Muwaqi'in dan al-Rūh. Lihat: Bakr bin Abdullāh Abu Zaid, Fiqh al-Nawāzil..., 19-21.

${ }^{21}$ Imam Yazid, "Taqnin al-Ahkam...., 196.

${ }^{22}$ Imam Yazid, “Taqnin al-Ahkam...., 196.

${ }^{23}$ Abdullah Tri Wahyuni, Peradilan Agama di Indonesia (Yogyakarta: Pustaka Pelajar, 2004), 3 .

${ }^{24}$ Islam telah masuk ke Sriwijaya berdasarkan cerita buku sejarah Cina yang menyebutkan bahwa Dinasti Tang memberitakan tentang utusan Tache (sebutan untuk Orang Arab) ke Kalingga pada tahun $674 \mathrm{M}$. Juga telah terdapat perkampungan muslim di pantai barat 93 | Ulümuna: Jurnal Studi Keislaman
} 
pelaksanaan ibadah-ibadah tertentu melainkan juga di terapkan dalam masalahmasalah muamalah, munakahat, dan ukubat (jinayah/ hudud) melalui pegawai khusus yang mempunyai keahlian dalam hukum Islam di tiap-tiap daerah yang menerpakan ajaran Islam. Hal tersebut diselesaikan melalui peradilan agama yang secara tertulis yuridis hal tersebut belum ada namun secara praktik dan penerapannya sudah ada yang dikenal dengan 3 periode, yaitu periode tabkim ${ }^{25}$, periode ablil billi wal Aqdi2 ${ }^{26}$ dan periode tabuliyah ${ }^{27}$.

Sebagaimana diungkapkan oleh Martin yang dikutip oleh Mahsun Fuad dalam bukunya Hukum Islam Indonesia bahwa "sulit bagi kita untuk memotret secara cukup sempurna perkembangan Islam di Indonesia sebelum abad XVIII M. Hal itu merupakan problem tersendiri ketika kita harus memotret karakteristik pemikiran hukum Islam yang terjadi pada saat itu mengingat eksistensinya telah ada bersamaan dengan masuknya Islam untuk pertama kalinya di Nusantara Ini. Memang sangat disayangkan, mengapa hal ini harus terjadi pada kasus hukum Islam, yang sejak kemunculannya telah menjadi hukum yang hidup (living law) di dalam masyarakat. Hukum dalam Islam adalah ruh yang juga sebagi aspek ajaran yang mendominasi dibanding dengan disiplin keilmuan tradisional mapan lainnya. Dengan demikian, dalam konteks ini,

Sumatera pada tahun 674 M. Lihat: Abdullah Tri Wahyuni, Peradilan Agama di Indonesia...., 4.

${ }^{25}$ Periode tahkim: belum ada masyarakat yang modern, pada periode ini masyarakat tergolong sederhana terdiri dari kelompok-kelompok yang dipimpin oleh kepala adat. Bila terjadi benturan-benturan tentang hal pribadi dalam kehidupan bermasyarakat, maka mereka serahkan kepada pemuka-pemuka agama atau ahli agaman hal ini lah yang kemudian disebut tahkim. Misalnya seorang wanita yang akan melakukan pernikahan kepada penghulu karena belum mengetahui masalh nikah sesuai agama Islam maka ia ber-tahkim kepada penghulu agama. Lihat: Abdullah Tri Wahyuni, Peradilan Agama di Indonesia...., 5.

${ }^{26}$ Periode ahlil hilli wal aqdi: terbentuknya masyarakat yang terorgnisir namun masih primitif tapi sudah ada kepala masyarakat dan seorang yang menjadi qadli atau hakim pengadilan agama yang dinobatkan oleh masyarakat tersebut. Hal ini terjadi tidak hanya di pulau jawa melainkan juga du luar jawa. Pada waktu sultan agung berkuasa di Mataram melakukan perubahan dalam tata hukum kerajaan dengan menjunjung tinggi hukum Islam. Peradilan yang bernama Peradilan Pradata di ubah menjadi Peradilan Surambi. Lihat: Abdullah Tri Wahyuni, Peradilan Agama di Indonesia...., 5-6.

${ }^{27}$ Periode tahuliyah: periode adanya pemisahan kekuasaan karena pengaruh teori trias politica yang memisahkan antara kekuasaan eksekutif, legislatif dan judikatif. Kewenangan dan kekuasaan mengadili diserahkan kepada kekuasaan judikatif. Lihat: Abdullah Tri Wahyuni, Peradilan Agama di Indonesia...., 6. 
pengetahuan kita hanya mampu memotret fenomena pemikiran hukum yang terjadi dan dimulai pada abad ke-17 M" ${ }^{28}$

Setelah melalui sejarah yang begitu panjang dari berbagai perubahan yang ada peng-qanünan-kodifikasi hukum -telah ada sejak awal pendirian bangsa Indonesia yang ditandai dari ide untuk memasukkan kewajiban melaksanakan syariat bagi pemeluk agama Islam. Di era orde baru, sebagian dari hukum Islam diakomodasi oleh pemerintah dengan adany undang-undang No. 14 Tahun 1970 tentang ketentuan-ketentuan pokok kekuasaan kehakiman. Berdasarkan pasal 10 ayat (1) peradilan agama merupakan salah satu lingkungan perdilan yang melaksanakan kekuasaan kehakiman di samping peradilan lainnya. Selain adanya kewenangan relatif dan absolut dalam ruang lingkup peradilan, semangat qanūn juga dibuktikan dengan lahirnya undang-undang perkawinan $(1974)^{29}$, peraturan pemerintah tentang wakaf $(1977)^{30}$, dan Kompilasi Hukum Islam $(1991)^{31}$. Di era reformasi, senmangat qanün terus berlanjut dan semakin besar baik melalui undang-undang atau peraturan daerah (PERDA), hingga akhirnya beberapa undang-undang maupun peraturan daerah yang berhubungan dengan hukum Islam telah lahir.

\section{Pandangan Ulama Terhadap Taqnīn al-Ahkām}

Seperti yang telah diketahui sebelumnya bahwa perkembangan taqnin mulai lebih tampak pada masa Utsmani, yakni tepatnya masa kepemimpinan Sultan Sulaiman (1520-1560 M). Hal ini menunjukkan bahwa perkembangan taqnin tidak lagi dalam masa ulama klasik, meskipun demikian pada masa ulama klasik sudah tampak hal-hal yang mengarah terhadap taqnin seperti adanya hakim yang harus mengikuti suatu pendapat dalam memutuskan suatu perkara yang tidak boleh dilanggarnya meskipun ia memiliki ijtihad sendiri ${ }^{32}$. Berkenaan

\footnotetext{
${ }^{28}$ Mahsun Fuad, Hukum Islam Indonesia; dari Nalar Partisipatoris Hingga Emansipatoris (Yogyakarta: LKIS, 2005), 34.

${ }^{29}$ Undang-undang yang dimaksud adalah undang-undang Nomor 1 tahun 1997 tentang perkawinan.

${ }^{30}$ Undang-undang wakaf ini telah di amandemen dengan undang-undang Nomor 41 tahun 2004 tentang wakaf.

${ }^{31}$ Kompilasi Hukum Islam (KHI) merupakan Instruksi Presiden (Inpres) Nomor 1 Tahun 1991 tanggal 10 Juni 1991.

${ }^{32}$ Ketika yang menjadi hakim ialah orang-orang yang memenuhi syarat ijtihad, maka yang menjadi rujukan dalam mengambil keputusan ialah hasil ijtihadnya dengan menjadikan alQur'an dan Sunnah sebagai dasarnya baik secara langsung atau melalui dali-dalil sekunder. Namun, apabila yang menjadi hakim bukan seorang mujtahid maka mau tidak mau harus 95 | Ulumunâ: Jurnal Studi Keislaman
} 
dengan penggunaan taqnin (kodifikasi hukum) sebagai pegangan dalam memutuskan hukum. Ada kbiläf atau perbedaan pendapat dikalangan ulama antara tidak setuju dan setuju berkenaa dengan taqnin itu sendiri:

\section{Ulama yang Tidak Setuju dengan Taqnīn al-Ahkām (Kontra-Taqnīn)}

Ulama yang tidak setuju dengan adanya taqnin al-abkäm mayoritas terdiri dari ulama klasik, baik dari kalangan Maliki, Syafi'i dan Hambali serta kedua murid Imam Abu Hanifah yaitu Abu Yusuf dan Muhammad bin al-Hasan. Ibnu Taimiyah dalam kitabnya Majmù' Fatāwà pada pembahasan bab qadla' mengatakan "para hakim dalam mengambil keputusan sebuah hukum harus bertendensi dengan hukum yang sudah Allah Swt. tetapkan, tidak boleh seorang hakim bertendensi atas keputusan seorang mahluk. Karena sejatinya hukum yang terjadi kepada mahluk sudah ditetapkan Allah (al-Qur'an) dan Rasulullah Saw. (al-Hadist). ${ }^{33}$

Sedangkan dari kalangan ulama kontemporer yang tidak setuju dengan adanya taqnin al-abkäm kebanyakan terdiri dari pembesar ulama Arab Saudi. Diantaranya adalah Syaikh Bakr bin Abdullah Abu Zaid, Syaikh Shalih bin Fauzan al-Fauzan, Syaikh Abdullah bin Abdurrahman al-Bassam, Syaikh Abdullah bin Abdurrahman al-Jabirin, Abdurrahman bin Abdullah al-Ajlan, Syaikh Abdullah Ibn Muhammad al-Ghunaiman, Syaikh Abdul Aziz bin Abdullah ar-Rajihi. ${ }^{34}$

Ada beberapa dasar berkenaa ulama yang tidak setuju dengan adanya taqnin al-abkam berikut sebagian alasan mendasar yang paling kuat dalam menolak taqnin:

a. Al-Qur'an

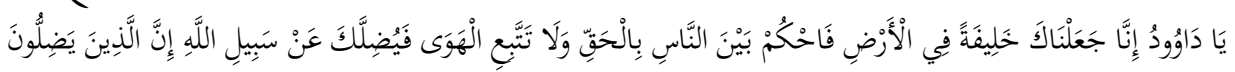

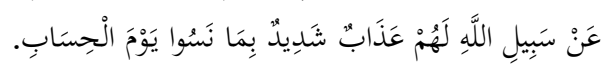

bertaklid dengan merujuk kepada hasil ijtihad fuqaha' yang tertuang di dalam kitab-kitab dalam berbagai madzhabnya. Meski demikian, terkadang terdapat kesulitan dalam merujuk kepada kitab-kitab fiqh. Kesulitan tersebut bisa diatasi dengan adanya taqnīn, yakni kodifikasi undang-undang. Bahkan, bagi hakim yang mujtahid pun kehadiran undangundang tetap di perlukan. Lihat: Afifuddin Muhajir, Fiqh Tata Negara; Upaya Mendialogkan Sistem Ketatanegaraan Islam (Yogyakarta: IRCiSoD, 2017), 159-160.

${ }^{33}$ Ahmad bin Taimiyah, Majmū' 'Fatāwā, Vol. 35 (Madinah: Wizārah al-Syu'ūn al-Islāmiyah wa al-Awqāf wa al-Da'wah wa al-Irsyād, 2004), 357.

${ }^{34}$ Bakr bin Abdullāh Abu Zaid, Fiqh al-Nawāzil; Qadlāyā Fiqhiyah Mu'āshirah...., 1. 
Artinya: "Hai Daud, sesunggubnya Kami menjadikan kamu khalifah (penguasa) di muka bumi, maka berilah keputusan (perkara) di antara manusia dengan adil dan janganlab kamu mengikuti hawa nafsu, karena ia akan menyesatkean kamu dari jalan Allah. Sesunggubnya orang-orang yang sesat dari jalan Allah akan mendapat adzab yang berat, karena mereka melupakan hari perbitungan". ${ }^{35}$

Ibn Qudamah mengatakan bahwa ayat di atas tidak terbatas pada madzhab tertentu dan besar kemungkinan kebenaran akan terdapat di luar madzhab yang diikuti oleh seorang hakim. ${ }^{36}$ Oleh karenanya, pemerintah tidak berhak melarang masyarakat (qadli) untuk melaksanakan hasil ijtihadnya dengan membatasi penggunaan ijtihad melalui taqnin atau qanün, melainkan pemerintah harus meringankan dan memberi keleluasaan kepada masyarakat.

Selain ayat di atas, ada juga ayat lain yang juga di jadikan sandaran atau alasan ketidak setujuan ulama terhadap taqnin atau qanün.

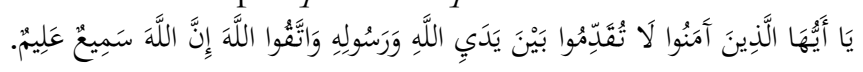

Artinya: "Hai orang-orang yang beriman, janganlah kamu mendabului Allah dan Rasul-Nya dan bertakwalah kepada Allah. Sesunggubnya Allah maha mendengar lagi maha mengetabui..$^{37}$

Dalam menetapkan hukum, seorang hakim harus tetap memegang teguh prinsip tauhid. Dalam hal ini kewajiban untuk petuh atas undang-undang menunjukkan adanya unsur meremehkan prinsip tauhid yaitu meninggalkan ketaatan hukum Allah Swt.

b. Taqnin membuat hakim terbelenggu karena harus terkait dengan salah satu pendapat tertentu, yaitu pendapat yang dipilih oleh pembuat undang-undang. sementara fiqh itu sangat kaya dengan pendapat dan hasil ijtihad fuqaba' sehingga memberi peluang bagi hakim supaya memilih salah satu pendapat yang diyakini lebih räjih (unggul), maslahah dan sesuai dengan kondisi dan situasi tertentu. ${ }^{38}$

\footnotetext{
${ }^{35}$ al-Qur'ān, al-Shad (38): 26.

${ }^{36}$ Abi Muhammad Abdullah bin Ahmad bin Muhammad bin Qudamah, al-Mughni, Vol. 14 (Riyad: Dar 'Ālim al-Kutub, 1997), 91.

${ }^{37}$ al-Qur'ān, al-Hujurat (49): 1.

${ }^{38}$ Afifuddin Muhajir, Fiqh Tata Negara...., 160.

$97 \mid$ Ulumuná: Jurnal Studi Keislaman
} 
c. Kerugian akibat taqnin akan tampak jelas ketika terjadi perubahan sosial yang menyebabkan ketentuan hukum menjadi tidak maslahah atau tidak relevan dengan keadaan. Sementara, hakim tidak bisa menyimpang dari ketentuan itu karena secara legal formal, taqnin tetap memiliki kekuatan hukum yang mengikat. ${ }^{39}$

d. Taqnin menciptakan kemalasan bagi para hakim dalam merujuk langsung pada sumber-sumber fiqh dan mendalami materi-materi hukum beserta dalilnya. Padahal, apabila hal itu dilakukan, akan memperluas wawasan para hakim dan membuat mereka selalu berkomunikasi dengan fiqh dan sumbersumbernya. ${ }^{40}$

Ulama meneilai adanya taqnin akan mempersempit ruang gerak ijtihad, sehingga penggunaan suatu hukum yang sudah ditentukan oleh pemerintah cendrung akan menimbulkan sifat enggan (ketidak ingin tahuan) seorang hakim kepada sumber-sumber asli dalam permasalahn fiqh. Sedangkan dalam fiqh terdapat beberapa pendapat ulama yang secara eksplisit menunjukkan adanya tuntutan berijtihad.

\section{Ulama yang Setuju dengan Taqnīn al-Ahkām (Pro-taqnīn)}

Abu Hanifah mengatakan, "seorang penguasa boleh mewajibkan para hakim untuk memutuskan suatu masalah menggunakan madzhab tertentu". Pendapatnya tersebut ditentang oleh kedua muridnya yaitu Abu Yusuf dan Muhammad bin al-Hasan. Pendapat Abu Hanifah tersebut menegaskan bahwa wewenang untuk mengadili dibatasi oleh tempat, waktu, dan diberikan kepada orang tertentu pula. Jika penguasa mengangkat seorang sebagai hakim maka jabatan itu dibatasi pada waktu dan tempat tertentu. Hal ini dikarenakan orang tersebut adalah petugas sebagai wakil penguasa. Jika penguasa membatasi hakim dan melarangnya menggunakan putusan atas madzhab yang ada maka hakim tidak melakukannya (mengikuti penguasa). Ia hanya boleh memutuskan berdasarkan kitab undang-undang yang telah disahkan penguasa. ${ }^{41}$

Mayoritas ulama kontemporer memperbolehkan taqnin al-abkäm, diantaranya adalah Shalih Ibn Ghashun, Abdul Majid Ibn Hasan, Abdullah Ibn

\footnotetext{
${ }^{39}$ Afifuddin Muhajir, Fiqh Tata Negara...., 160.

${ }^{40}$ Afifuddin Muhajir, Fiqh Tata Negara...., 160-161.

${ }^{41}$ Jaenudin, "Pandangan Ulama Tentang Taqnin Ahkam" 'Adliya; Jurnal Hukum dan Kemanusiaan, No. 1, Vol. 11 (2017), 47.
} 
Mani', Abdullah Khayyath, Muhammad Ibn Jabir, Rasyid bin Hunain. Selain mereka juga terdapat ulama masa kini seperti Musthafa al-Zarqa, Muhammad Abu Zahrah, Yusuf al-Qardhawi dan Wahbah al-Zuhaili. ${ }^{42}$ Ada beberapa dasar yang digunakan untuk memperkuat asumsi mereka, sebagian dari dasar yang digunakan untuk memperkuat pendapatnya tersebut adalah:

a. Al-Qur'an

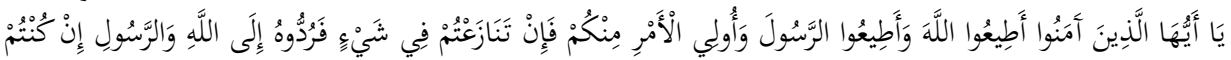

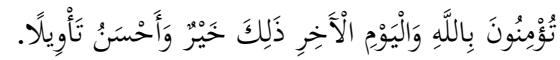

Artinya: "Hai orang-orang yang beriman, taatilah Allab dan taatilab Rasul (Nya), dan ulil amri di antara kamu. Kemudian jika kamu berlainan pendapat tentang sesuatu, maka kembalikanlah ia kepada Allab (al-Qur'an) dan Rasul (sunnab), jika kamu benar-benar beriman kepada Allah dan hari akbir. Yang demikian itu lebih utama (bagimu) dan lebih baik akibatnya".

Ayat di atas menjelaskan adanya tuntutan patuh atau taat kepada Allah dalam artian perintah-perintah Allah lewat al-Qur'an dan patuh pula kepada Rasul (utusan) Allah, selain itu ayat ini juga menjelaskan adanya perintah untuk patuh kepada "ulil amri" ${ }^{* 3}$, pemimpin atau orang yang memiliki wewenang kekuasaan. Berdasarkan definisi taqnin atau qanün yang merupakan perundang-undangan yang sifatnya mengikat, sudah disepakati dan ditetapkan oleh pemerintah.

b. Diantara sekian banyak hakim, justru ada yang perlu diikat dengan taqnin agar tidak sembarangan dalam mebuat keputusan. Sebab tidak semua hakim

\footnotetext{
${ }^{42}$ Jaenudin, "Pandangan Ulama Tentang Taqnin..., 47.

${ }^{43}$ Ahmad Mustafa al-Marāghi menjelaskan yang dimaksud "ulil amri" adalah pemerintah (pemimpin). Baik pemerintah tersebut yang tertinggi atau pemerintah yang ada di bawahnya, dimana tugasnya adalah memelihara ke maslahatan umat manusia. Dengan demikian aturanaturan yang dibuat oleh pemerintah untuk kemaslahatan manusia wajib ditaati selama aturan-aturan tersebut tidak bertentangan dengan al-Qur'an dan al-Hadis. Sedangkan menurut imam Karakhi yang dimaksud "ulil amri" adalah pemimpinnya orang muslimin dimasa Nabi dan masa-masa setelahnya dan termasuk dalam hal "ulil amri" adalah khulafä " al-Rāshidūn, qāḍ dan para pemimpin perang. Ada yang mengemukakan pula bahwa yang dimaksud "ulil amri" adalah para ulama atau pemuka-pemuka agama. Lihat: Ahmad Mustafa al-Marāghi, Tafsīr al-Marāghi, Vol. 5 (Mesir: t.p., 1946), 72. Lihat pula: Sulaimān bin 'Umar al-'Aj̄̄lī al-Jamal, al-Futūhāt al-Ilahiyah bi Taudīh Tafsìr Jalālain li al-daqāiq al-Khäfiyah, Vol. 2 (Beirut: Dar al-Kutub al-Islamiyah, 2011), 73.

$99 \mid$ Ulümnâ: Jurnal Studi Keislaman
} 
memiliki kemapuan untuk men-tarjih atau memilih salah satu diantara sekian banyak pendapat. Selain itu, hakim yang bisa berijtihad dengan sendirinya sudah menjadi mahluk langka, bahkan boleh dikatakan tidak ada pada zaman sekarang. ${ }^{44}$

c. Emosi dan kepentingan pribadi hakim selalu dikhawatirkan berpengaruh terhadap pengambilan keputusan. Kekhawatiran tersebut menjadi besar apabila tidak ada acuan hukum yang berupa taqnin atau qanün. ${ }^{45}$

d. Dengan adanya taqnin atau qanūn, masyarakat memiliki pengetahuan tentang hal yang boleh atau harus dilakukan dan yang tidak boleh dilakukan. Dengan demikian, orang yang sedang berperkara memiliki pengetahuan tentang arah keputusan hakim, meskipun secara global. ${ }^{46}$

e. Pendapat ulama yang setuju dengan adanya taqnin atau qanūn ini dinilai lebih kuat serta lebih realistis jika diterapkan pada masa sekarang. Selain itu kehadiran kitab undang-undang juga dinilai tidak menjadi penghalang bagi hakim untuk berijtihad, berkreasi dan berinovasi.

Adanya ikhtilaf (perbedaan pendapat) dikalangan ulama antara setuju dan tidak setuju atas penerapan sesuatu baik itu hukum atau yang lainnya merupakan ciri khas tersendiri dalam dunia ke-Islaman. Afifuddin Muhajir lebih memilih pendapat yang kedua yaitu pro-taqnin, menurutnya adanya taqnin atau qanün yang harus dipatuhi oleh para hakim, masih menyisakan dua ruang agar seorang hakim beraktivitas dengan ijtihad.

Pertama, ijtihad ketika tidak ada teks hukum. sebuah jargon yang menyatakan bahwa teks hukum jumlahnya terbatas dan peristiwa hukum tidak terbatas (النصوص تناهي و الوقائع لا تتناهي), merupakan realitas hukum yang tidak bisa dipungkiri. Berpegang pada jargon tersebut, fuqaha' meniscayakan terus dibukanya pintu ijtihad sepanjang zaman, baik untuk melahirkan ketentuan hukum bagi kasus-kasus yang belum ada ketentuan hukumnya, maupun untuk menelaah kembali (review) ketentuan-ketentuan hukum yang sudah ada, tetapi dinilai tidak relevan dengan kondisi zaman. ${ }^{47}$

Keterbatasan teks tidak hanya diperuntukkan untuk al-Qur'an dan alHadist, tetapi undang-undang juga mengalami keterbatasan. Seberapa luas undang-undang itu terkodifikasi tetap saja tidak mungkin menjangkau semua

\footnotetext{
${ }^{44}$ Afifuddin Muhajir, Fiqh Tata Negara...., 161.

${ }^{45}$ Afifuddin Muhajir, Fiqh Tata Negara...., 161.

${ }^{46}$ Afifuddin Muhajir, Fiqh Tata Negara...., 161-162.

${ }^{47}$ Afifuddin Muhajir, Fiqh Tata Negara...., 162-163.
} 
persoalan atau kasus yang terjadi di masyarakat. Sementara itu, seorang hakim dituntut untuk memberikan putusan dalam setiap perkara yang dihadapi. Pada saat posisi inilah peran ijtidad seorang hakim menjadi penentu putusnya sebuah persoalan hukum.

Kedua, ijtihad dalam tataran penerapan teks hukum. Bagi sebagian kalangan, telah lumrah bahwa adanya ijtihad tidak hanya bertujuan melahirkan hukum dari al-Qur'an dan sunnah secara langsung atau tidak lanngsung, melainkan juga dalam rangka menerapkan ketentuan hukum yang sudah siap pakai pada suatu kasus. Ijtihad dalam bentuk ini tetap diperlukan meskipun ketentuan hukum yang hendak diterapkan sangat jelas dan tegas, karena diambil dari dalil yang qath'i dari segi wurud (datangnya dari wahyu) dan dalalah-nya (indikasi hukumnya). ${ }^{48}$

Dengan demikian, adanya taqnin atau butiran peraturan yang sudah terkodifikasi kedalam kitab undang-undang tidak mebuat hakim terbelenggu dengan tercegahnya melakukan ijtihad. Justru dengan adanya kodifikasi undangundang ini seorang hakim diharapkan lebih banyak lagi dalam melakukan pertimbangan (ijtihad) dalam menetapkan hukum.

\section{Legislasi Hukum Perdata Islam dalam Hukum Nasional di Indonesia}

Pasca-jatuhnya kerajaan Islam terakhir, Turki Ustmani, pada abad ke-19 $\mathrm{M}$, penjajahan barat mulai memasuki wilayah-wilayah kekuasaan Islam. Isu negara bangsa dengan tingkat keragaman penduduk mulai banyak di gulirkan oleh banyak kalangan. Menurut para negarawan dan pemuka agama adanya pengangkatan isu negara bangsa bertujuan untuk merumuskan kembali sistem ketatanegaraan yang sesuai dengan semangat perubahan. Berbagai tantangan dan harapan ikut mendorong mereka agar mencari penyelesaian, baik secara politis maupun akademis. Lalu sistem syura atau demokrasi yang pernah tersemai pada periode pemerintahan keempat dalam Islam (kbulafa al-rasyidun) kembali diembuskan dalam berbagai forum dan kesempatan. ${ }^{49}$

Indonesia sebagai negara dengan tingkat keragaman penduduk yang terbilang sangat tinggi ikut mewacanakan bentuk dan dasar negara yang hendak dirumuskan. Setelah merdeka dari kungkungan penjajah pada tahun 1945, para pemuka dan founding father republik ini sepakat bahwa sitem pemerintahan yang

\footnotetext{
${ }^{48}$ Afifuddin Muhajir, Fiqh Tata Negara...., 162-163.

${ }^{49}$ Afifuddin Muhajir, Fiqh Tata Negara...., 21.

101 | Ulumunâ: Jurnal Studi Keislaman
} 
akan digunakan adalah demokrasi ${ }^{50}$, sementara Pancasila menjadi dasar dan idiologi dalam kehidupan berbangsa dan bernegara.

As'ad Said Ali mengatakan dalam kutipan Afifuddin Muhajir dalam bukunya Fiqh Tata Negara, bahwa adanya Pancasila merupakan suatu konsesnsus dasar yang menjadi syarat utama terwujudnya bangsa yang demokratis. Ia juga mengemukakan bahwa ide pemikiran politik yang ada di dalam Pancasila merupakan racikan sempurna yang dapat memberikan solusi demi terwujudnya negara demokrasi dengan segmen penduduk yang sangat majemuk. Para pendiri negeri ini sangat kreatif dengan mengambil jalan tengah antara dua pilihan ekstrem yaitu negara sekuler dan negara agama. Mereka menyusun dengan rumusan imajinatif, yakni negara berdasarkan atas Ketuhanan Yang Maha Esa. ${ }^{51}$

Seperti yang telah diketahui bersama bahwa Indonesia bukanlah negara dengan paham teokrasi. Yaitu, menuntut adanya negara dan agama dipahami sebagi dua hal yang tidak dapat dipisahkan. Yakni dijalankan berdasarkan firman-firman tuhan sehingga tata kehidupan masyarakat, bangsa dan negara dilakukan dengan titah tuhan dalam kehidupan umat manusia. Pada dasarnya, paham ini akan melahirkan konsep negara agama dengan menjadikan agama resmi sebagai hukum positif. Bukan pula paham sekuler, yang memisahkan antara agama dan negara secara diamentral. Paham ini melahirkan konsep agama dan negara merupakan dua etnis yang berbeda dan satu sama lain mempunya garapan masing-masing sehingga tidak boleh ada intervensi diantara keduanya. ${ }^{52}$ Akan tetapi, Indonesia adalah negara hukum (rechtstaat) dengan sistem demokrasi. ${ }^{53}$ Antara agama dan negara di Indonesia tidak dapat dipisahkan sehingga ada relasi diantara keduanya. Agama dan negara merupakan hal yang berbeda. Namun, keduanya keduanya dipahami saling membutuhkan secara timbal balik. Sebagaimana ungkapan Afifuddin Muhajir, bahwa hadirnya negara merupakan sebuah konsekuensi logis dari adanya aturan-aturan syariat yang tidak mungkin terlaksana tanpa kehadiran negara. Dengan demikian, kehadiran negara menjadi syarat dan instrumen bagi terlaksananya aturan-aturan syariat. ${ }^{54}$

\footnotetext{
${ }^{50}$ Negara Demokrasi adalah sistem dimana seorang pemerintah memberi kekuaasaan sepenuhnya kepada rakyat.

${ }^{51}$ Afifuddin Muhajir, Fiqh Tata Negara; Upaya Mendialogkan Sistem Ketatanegaraan Islam, 21.

${ }^{52}$ Afifuddin Muhajir, Fiqh Tata Negara...., 41.

${ }^{53}$ Pasal 1 ayat (3) Undang-Undang Dasar Negara Republik Indonesia Tahun 1945.

${ }^{54}$ Afifuddin Muhajir, Fiqh Tata Negara...., 69. 
Adanya timbal balik bahwa agama membutuhkan negara sebagai instrumen dalam melestarikan dan mengembangkan agama. Begitu pula sebaliknya, negara membutuhkan agama dalam pembinaan moral, etika dan spiritualitas. Timbal balik inilah yang kemudian disebut dengan pradigma. Dalam konteks ke-Indonesia-an pradigma seperti ini disebut dengan pradigma simbolik, dimana kedudukan hukum Islam menempati posisi strategis sebagai sumber legitimasi untuk menegakannya dalam porsi yang proporsional. ${ }^{55}$

Meski Islam menjadi agama dengan penganut terbanyak di Indonesia bahkan di dunia. Namun, Indonesia bukanlah sebuah negara Islam tetapi sebuah negara Nasional yang tidak memberi tempat pada umat Islam untuk melaksanakan hukum Islam tetapi juga kepada umat-umat penganut agama lain dalam hal ini Kristen Protestan, Khatolik, Hindu dan Budha. Akan tetapi, secara formal negara juga tidak sepenuhnya menutup mata dari pelaksanaan hukum Islam sehingga di samping punya landasan dokmatik pada ajaran agama, keberadaan umat Islam juga didukung oleh umatnya dan untuk sebagian mempunyai landasan formal dari kekuasaan negara Republik Indonesia. ${ }^{56}$ Berhubung Indonesia sebagai negara hukum. Maka, hukum agama di Indonesia diposisikan sebagai sumber hukum materiil (dalam Islam; fiqh) sedang hukum tertulis seperti perundang-undangan disebut sebagi hukum formil atau formal.

Legislasi hukum Islam ke dalam sistem hukum nasional di Indonesia perlu adanya peran lembaga-lembaga yang berwenang dalam pembentukan perundang-undangan. Ada lembaga yang berperan penting dalam hal melegislasikan sebuah produk hukum, lembaga tersebut diistilahkan dengan nama legislatif. ${ }^{57}$ Lembaga ini mempunyai kedudukan yang sangat strategis dalam sitem tata kelola negara, tak terkecuali dalam hal melegislasi sebuah produk hukum menjadi undang-undang.

\footnotetext{
${ }^{55}$ Ujang Ruhyat Syamsoni, "Taqnin al-Ahkam (Legislasi Hukum Islam ke dalam Hukum Nasional)" Nur El-Islam, No. 2, Vol. 2 (Oktober 2015), 188.

${ }^{56}$ Abdurrahman, Kompilasi Hukum Islam di Indonesia (Jakarta: CV Akademika Pressindo, 2010), 1 .

${ }^{57}$ Pemerintahan Indonesia menerapkan teori trias politika. Trias politika merupakan pembagian kekuasaan pemerintah menjadi tiga bidang yang memiliki kedudukan sejajar. 1). Legislatif: bertugas membuat undang-undang. Seperti, Dewan Perwakilan Rakyat (DPR). 2). Eksekutif: bertugas menerapkan atau melaksanakan undang-undang. Seperti, Presiden dan Wakil Presiden. 3). Yudikatif: bertugas mempertahankan pelaksanaan undang-undang. Seperti, Mahkamah Agung (MA) dan Mahkamah Konstitusi (MK).
}

103 | Ulumunâ: Jurnal Studi Keislaman 
Berdasarkan sejarah perkembangannya, hukum Islam masuk di Indonesia bersamaan masuknya agama Islam di negri ini. ${ }^{58}$ Pada zaman VOC kedudukan hukum Islam dalam bidang ke keluargaan di akui bahkan dikumpulkan dalam sebuah kumpulan peraturan yang dinamakan compendium freyer, serta pada masa itu sudah dibuat kumpulan hukum perkawinan dan kewarisan Islam untuk daerah Cirebon, Semarang dan Makasar. Selain itu pada tahun 1937 pemerintah Hindia-Belanda mengeluarkan kewarisan dari kewenangan Peradilan Agama di Jawa dan Madura. Setelah Indonesia merdeka, hukum Islam yang berlaku terserak-serak di berbagai kitab fiqh dengan pendapat yang beragam. Undnag-Undang Nomor 22 Tahun 1946 dan UndangUndang Nomor 32 Tahun 1954 dimaksudkan untuk memenuhi kebutuhan mendesak akan adanya kesatuan dan kepastian hukum dalam pencatatan nikah, talak dan rujuk umat Islam. ${ }^{59}$

Terkait proses legislasi hukum Islam itu sendiri ada dua langkah yang harus dilalui, yaitu proses demokrasi dan program legislasi nasional (prolegnas) $^{60}$. Proses demokrasi harus melalui musyawarah mufakat yang kemudian hasil musyawarah tersebuh nantinya dituangkan kedalam program legislasi nasional (prolegnas). Hukum Islam yang berupa materiil (fiqh) untuk menjadi hukum positif diperlukan kajian lebih mendalam melalui beberapa naskah akademik karena menyangkut tujuan dari berbagai macam aspek. Baik sosiologis, politis, ekonomis maupun filosofis. Hal ini sebagaiman diatur dalam undang-undang No. 10 tahun 2004 yang kemudian di ubah menjadi undangundang No. 12 tahun 2011 tentang Pembentukan Peraturan Perundang-

\footnotetext{
${ }^{58}$ Terdapat tiga teori tentang masuknya Islam ke Nusantara. Pertama teori Gujarat (India); awal penyebaran Islam di Indonesia pada abad ke-13 M. Tempat asalnya Gujarat dan pelakunya adalah para pedagang India yang telah memeluk agama Islam. Kedua teori Mekkah (Arab); penyebaran Islam terjadi pada abad ke-7 M sedang pelakunya terdapat dua versi ada yang berpendapat dari Gujarat, sedang pendapat lain mengatakan dari daerah Timur Tengah yaitu Mekkah. Ketiga teori Persia; Islam masuk ke Nusantara berasal dari Persia, singgah di Gujarat dan hal ini terjadi pada abad ke-13 M. Lihat: A. Malthuf Siroj, Pembaruan Hukum Islam di Indonesia; Telaah Kompilasi Hukum Islam (Yogyakarta: Pustaka Ilmu, 2012), 1-2.

${ }^{59}$ A. Basiq Djalil, Peradilan Agama di Indonesia (Jakarta: Kencana Prenada Media Group, 2012), 108.

${ }^{60}$ Prolegnas disusun oleh DPR bersama Pemerintah yang dalam penyusunannya dikordinasikan oleh DPR. Kordinasi yang dilakukan oleh DPR merupakan konsekuensi logis dari hasil amandemen pertama UUD 1945 yang menggeser penjuru atau titik berat pembentukan undang-undang dari pemerintah ke DPR.
} 
Undangan. Setelah melalui sejarah yang cukup panjang akhirnya ada beberpa norma-norma hukum Islam yang sudah menjadi hukum positif. Seperti, yang berkaitan dengan akuntabilitas publik atau tanggung jawab publik, yaitu undangundang tentang zakat ${ }^{61}$, wakaf ${ }^{62}$, haji $1^{63}$, peradilan agama ${ }^{64}$, bank syariah ${ }^{65}$ dan Kompilasi Hukum Islam (KHI) ${ }^{66}$.

Berdasarkan pasal 15 ayat (1) Undang-Undang Nomor 10 tahun 2004 tentang Pembentukan Peraturan Perundang-Undangan menegaskan bahwa, "perencanaan penyusunan undang-undang dilakukan dalam satu Program Legislasi Nasional". ${ }^{77}$ Berdasarkan hal tersebut, dapat dipahami bahwa prolegnas merupakan "wadah" politik hukum (untuk jangka waktu tertentu ). Ayat (2) setelahnya menegaskan, "perencanaan penyusunan peraturan daerah dilakukan dalam suatu Program Legislasi Daerah". ${ }^{68}$ Dengan demikian dapat dipahami bahwa pembentukan undang-undang atau legislasi ditangani pemerintah mulai dari tingkat pusat hingga daerah. Dapat disimpulkan bahwa dengan adanya prolegnas setiap jenis undang-undang yang akan dibuat untuk jangka tertentu sebagai politik hukum.

Berdasarkan pembahasan di atas, prolegnas dapat dianggap baik sebagai isi atau materi hukum yang akan dibuat atau sebagai instrumen mekanisme perencanaan hukum. Sebagai isi hukum, prolegnas memuat daftar rencana materi-materi hukum (RUU) yang akan dibentuk dalam priode tertentu guna meraih tahap tertentu dalam mencapai cita-cita bangsa dan tujuan negara. Sebagai instrumen perencanaan hukum, prolegnas menentukan cara dan prosedur yang harus ditempuh agar pembentukan undang-undang tidak keluar dari landasan dan arah konstitusionalnya. Dengan demikian, prolegnas merupakan potret politik hukum nasional yang memuat tentang rencana materi sekaligus merupakan instrumen (mekanisme) pembuatan hukum.

\footnotetext{
${ }^{61}$ Undang-Undang No. 23 Tahun 2011 Tentang Pengelolaan Zakat.

${ }^{62}$ Undang-Undang No. 41 Tahun 2004 Tentang Wakaf.

${ }^{63}$ Undang-Undang No. 8 Tahun 2019 Tentang Penyelenggaraan Haji dan Umarah.

${ }^{64}$ Undang-Undang No. 7 Tahun 1989 Tentang Peradilan Agama.

${ }^{65}$ Undang-Undang No. 21 Tahun 2008 Tentang Perbankan Syariah.

${ }^{66}$ Kompilasi Hukum Islam (KHI) merupakan Instruksi Presiden (Inpres) Nomor 1 Tahun 1991 tanggal 10 Juni 1991.

${ }^{67}$ Undang-Undang Republik Indonesia Nomor 10 Tahun 2004 Tentang Pembentukan Peraturan Perundang-Undangan.

${ }^{68}$ Undang-Undang Republik Indonesia Nomor 10 Tahun 2004 Tentang Pembentukan Peraturan Perundang-Undangan.
}

105 | Ulumunâ: Jurnal Studi Keislaman 


\section{Kesimpulan}

Pada masa sekarang ini, qanūn dipandang sebagai legislasi hukum Islam, yakni aturan syara' yang bersifat living law oleh pemerintah dijadikan bersifat mengikat dan berlaku secara umum. Lahirnya qanūn (legislasi hukum Islam) dalam era moderen dalam suatu sisi dianggap sebagai kemajuan Islam dalam mengembangkan syariat-Nya serta menegakkan hukum-hukum yang ada di dalamnya. Atas dasar ini, sebagian ulama menganggap formulasi hukum Islam sebagai suatu yang penting, sebagai panduan putusan hukum bagi para hakim dalam memutuskan masalah yang sama di peradilan yang berbeda-beda.

Secara praktik keagmaan, hukum Islam sudah mulai diterapkan pada masa itu. Namun secara tertulis pemberlakuan hukum Islam di Indonesia ada sejak zaman VOC, dimana kedudukan hukum Islam dalam bidang ke keluargaan di akui bahkan dikumpulkan dalam sebuah kumpulan peraturan yang dinamakan compendium freyer, serta pada masa itu sudah dibuat kumpulan hukum perkawinan dan kewarisan Islam untuk daerah Cirebon, Semarang dan Makasar. Selain itu pada tahun 1937 pemerintah Hindia-Belanda mengeluarkan kewarisan dari kewenangan Peradilan Agama di Jawa dan Madura. Setelah Indonesia merdeka, hukum Islam yang berlaku terserak-serak di berbagai kitab fiqh dengan pendapat yang beragam. Undnag-Undang Nomor 22 Tahun 1946 dan UndangUndang Nomor 32 Tahun 1954 dimaksudkan untuk memenuhi kebutuhan mendesak akan adanya kesatuan dan kepastian hukum dalam pencatatan nikah, talak dan rujuk umat Islam.

Berhubung Indonesia sebagai negara hukum. Maka, hukum agama di Indonesia diposisikan sebagai sumber hukum materiil (dalam Islam; fiqh) sedang hukum tertulis seperti perundang-undangan disebut sebagi hukum formil atau formal. Legislasi hukum Islam ke dalam sistem hukum nasional di Indonesia perlu adanya peran lembaga-lembaga yang berwenang dalam pembentukan perundang-undangan. Ada lembaga yang berperan penting dalam hal melegislasikan sebuah produk hukum, lembaga tersebut diistilahkan dengan nama legislatif.

\section{Daftar Pustaka}

Abdu al-Bar, Muhammad Zakī. 1986. Taqnīn al-Fiqh al-Islämï; al-Mabdä’ wa alManhaj wa al-Tathbiq. Qatar: Idarah Ihya' al-Turats al-Islamī. 
Abdurrahman. 2010. Kompilasi Hukum Islam di Indonesia. Jakarta: CV Akademika Pressindo.

Abu Zaid, Bakr bin Abdullāh. 1996. Fiqh al-Nawāàil; Qadlāyà Fiqhiyah Mu'āshirah. Vol. 1. Beirut: Muassasah al-Dirāsah.

al-Anshorī, Zakariya. t.t. Ghāyah al-Wushül Syarh Lubbu al-Ushül. Surabaya: alHidāyah

Ali, Atabik \& Muhdlor, A. Zuhdi. t.t. Kamus Kontemporer: Arab-Indonesia. Yogyakarata: Multi Karya Grafika.

al-Jamal, Sulaimān bin 'Umar al-'Ajīlī. 2011. al-Futūhät al-Ilahiyah bi Taudīh Tafsìr Jalālain li al-daqäiq al-Khäfiyah. Vol. 2. Beirut: Dar al-Kutub alIslamiyah.

al-Malībārī, Zain al-Dīn bin Abdu al-'Azīz. t.t. Fath al-Mu'ìn. t.tp: Gerbang Andalus.

al-Marāghi, Ahmad Mutofa. 1946. Tafsìr al-Maräghi. Vol. 5. Mesir: t.p.

al-Qaththān, Mannā'. 1997. Tarikh al-Tasyri' al-Islämī; al-Syarì'ah wa al-Fiqh. Riyad: Maktabah al-Ma'arif li al-Nasyri wa al-Tauzi'.

al-Qur'ān.

al-Zarqā, Musthafa Ahmad. 2004. al-Madkhal al-Figh al-'Ámì. Vol. 1. Beirut: Dar al-Qalam.

Anis, Ibrahim. 1987. al-Mujjam al-Wasith. Vol. 2. Beirut: Dar al-Ilmiyah.

Djalil, A. Basiq. 2012. Peradilan Agama di Indonesia (Jakarta: Kencana Prenada Media Group.

Fuad, Mahsun. 2005. Hukum Islam Indonesia; dari Nalar Partisipatoris Hingga Emansipatoris. Yogyakarta: LKIS.

Ibn Hamdūn. t.t. Hasyiyah Ibn Hamdūn. Vol. 1. Surabaya: al-Hidayah. 
Ibn Taimiyah, Ahmad. 2004. Majmū Fatāwā, Vol. 35. Madinah: Wizāahah alSyu'ūn al-Islāmiyah wa al-Awqāf wa al-Da'wah wa al-Irsyād.

Jaenudin, 2017. "Pandangan Ulama Tentang Taqnin Ahkam" 'Adliya; Jurnal Hukum dan Kemanusiaan. No. 1, Vol. 11:

https://Journal.uinsgd.ac.id/index.php/adliya/article/download/ 4851/pdf. (diakses pada 3 Maret 2020).

Mubarok, Jaih. 2006. Hukum Islam. Bandung: Benang Merah Press.

Muhajir, Afifuddin. 2017. Figh Tata Negara; Upaya Mendialogkan Sistem Ketatanegaraan Islam. Yogyakarta: IRCiSoD.

Munawwir, Ahmad Warson. 1997. Kamus al-Munawnir: Arab-Indonesia. Surabaya: Pustaka Progressif.

Rohidin. 2016. Pengantar Hukum Islam dari Semenanjung Arabia Sampai Indonesia. Yogyakarta: Lintang Rasi Aksara Books.

Siroj, A. Malthuf. 2012. Pembaruan Hukum Islam di Indonesia; Telaah Kompilasi Hukum Islam. Yogyakarta: Pustaka Ilmu.

Syamsoni, Ujang Ruhyat. 2015. Taqnin al-Ahkam (Legislasi Hukum Islam ke dalam Hukum Nasional). Nur El-Islam. No. 2, Vol. 2: https://www.neliti.com/publication/226413/taqnin-al-ahkamlegislasi-hukum-islam-ke-dalam-hukum-nasional. (diakses pada 5 Maret 2020).

Syarif, Mujar Ibnu \& Zada, Khamami. 2008. Fiqh Siyasab; Doktrin dan Pemikiran Politik Islam. t.tp: Erlangga.

Undang-Undang Dasar Negara Republik. Indonesia Tabun 1945.

Undang-Undang Republik Indonesia Nomor 10 Tabun 2004 Tentang Pembentukan Peraturan Perundang-Undangan.

Wahyuni, Abdullah Tri. 2004. Peradilan Agama di Indonesia. Yogyakarta: Pustaka Pelajar. 
Yazid, Imam. 2015. "Taqnin al-Ahkam; Sejarah, Keabsahan dan Tantangan di Indonesia" al-Mashlahah Journal Hukum dan Pranata Sosial Islam, No. 05, Vol. 3:

https://jurnal.staialhidayahbogor.ac.id/index.php/am/article/do wnload/140/138. (diakses pada 3 Maret 2020).

Zaidan, Abdul Karim. 1969. al-Madkhäl li al-Darasah al-Syariah al-Islämiyah. Beirut: Resalah Publisher. 